\title{
Modelling the optimal size of investment portfolio in a non-state pension fund
}

\author{
Mykhailo Luchko \\ Ternopil National Economic University, Ukraine \\ m_luchko@ukr.net \\ ORCID 0000-0001-6499-4188
}

Grzegorz Lew

Rzeszón University of Technology, Poland

lewgrzes@prz.edu.pl

ORCID 0000-0002-0067-8562

\section{Ruslana Ruska}

Ternopil National Economic University, Ukraine

r_ruslana@ukr.net

ORCID 0000-0002-1854-9734

\section{Iryna Vovk}

Ternopil Ivan Puluj National Technical University, Ukraine

vovk.ira.2010@gmail.com

ORCID 0000-0002-4617-516X

Abstract. The article presents a model based on the calculations of optimal size of the investment portfolio for a non-state pension fund (NPF). There are risks associated with the functioning of NPFs and their seemingly non-profit organization status. The primary risk in this regard is related to attracting solvent enough participants which will ensure future payouts. To achieve our research goals, we used the elements of data mining results technology, more specifically, the MARSPline module in the Statistica application package. This program allows constructing a regression model in multidimensional space as well as a spline surface depending on income payments to the pension fund and investment incomes and expenses from retirement assets. The resulting regression model has established the connections between the variables with a rather precise approximation. It can be applied not only to NPF activities, but also with insurance organizations and other financial intermediaries. Purpose. The purpose of this study is to build an economic and mathematical model for the formation of an investment portfolio in the NPF. This portfolio minimizes initial

Received:

October, 2018

1st Revision:

December, 2018

Accepted:

February, 2019

DOI:

10.14254/2071 $8330.2019 / 12-1 / 16$ 
investments and provides future payouts to participants. Its application in practice will minimize the risks from economic activities or at least scale them down to the level of justifiable risk. Methodology. In the process of writing the article, a systematic approach was used. Methods of economic and mathematical modeling were used in the process of model construction. These methods include regression dependence, analogue methods, retrospective analysis, and a classical method of hypothesising. Testing of theoretical developments was carried out in Statistica with the use of the MARSPline module. Theoretical contribution. Different methods and approaches to the evaluation of activities of a non-state pension funds are analyzed. The main factors influencing the payouts to NPF participants have been identified and a regression model of the optimal size of investment portfolio is constructed, establishing connections between them with a precise approximation. Practical implications. The offered and tested here economic-mathematical model of the NPF investment portfolio minimizes the initial investment and ensures future payouts to participants.

Keywords: non-state pension fund, payouts, investment portfolio, economicmathematical model, spline surface, regression model, data mining, MARSPline, Statistica package.

JEL Classification: G20, G23.

\section{INTRODUCTION}

Contemporary compulsory state pension system in Ukraine is not able to provide a decent standard of living for people when they reach retirement age. Constant deficit of the Pension Fund of Ukraine requires significant borrowings from the state budget and issuance of funds by the National Bank of Ukraine. Due to the rise in the minimum pension age during 2017-2019, the volume of these borrowings has only increased. Requirements of the International Monetary Fund in relation to pension system modernization have led to an increase in monthly expenses of the state pension system. Under such circumstances, one of the areas in the state pension policy is development of institutional support for NPFs (Bilan, Gazda, \& Godziszewski, 2012). The latter enable the creation of additional sources to guarantee pension payments thus allowing for significant reduction of the financial burden on the budget.

NPF has been operating in Ukraine since 2004. However, for almost 15 years, voluntary investment in future pensions has not become a mass phenomenon. The study of the causes and different approaches to NPF activity, improvement of their work and adaptation to the requirements of the present day is a priority task. NPF is a modern financial non-banking institution that works only for the provision of pensions to its depositors and has the status of a non-profit organization. The Fund accepts depositors' pension contributions and then invests them in lucrative, highly profitable projects for their growth and protection against impairment. Consequently, it conducts pension payments from participants to participants using the accumulated pension assets. The NPF is a relatively new financial institution for the vast majority of Ukraine's population. However, in the world, such funds are among the most popular means of savings, including those for aging, as opposed to bank deposits and/or investments in foreign currency. Non-state pension is paid in addition to the state pension. The size of the non-state pension depends on the size of pension contributions, the accumulation period and the amount of the received investment income. 
The NPF accumulates funds of the participants, therefore, it has a powerful internal source of financial investments (Gazda \& Puziak, 2012). Therewith, a large period of time between pension contributions and their payments, inflationary changes in the economy, reducing purchasing power of money and their future value may lead to a conflict of interest (FrostRB, 2012).

One can invest their money in government bonds, municipal bonds, corporate bonds, stocks, real estate (cf. Głuszak, 2018; Luchko, 2017; Mačí \& Valentová Hovorková, 2017; Rozhelyuk, Khorunzhak, \& Luchko, 2018; Vychytilova, 2018), deposits and bank metals. For NPF there are clear requirements for diversification of assets. Here is the structure of the portfolio of the "OTP Pension": 49.47\% - cash and deposits, 45.09\% - government bonds, 2.71\% - banks' bonds and 2.73\% other assets (VSE, 2012).

Each NPF is required to publish information and reports on the Fund's activities on a regular basis. Each member of the Fund monitors the status of a retirement account through their personal office. Certainly, an NPF cannot be called an ideal instrument, because in Ukraine they have their own weaknesses (anchoring to the national currency which is a constant subject to depreciation, non-guaranteed incomes and low level of public confidence in private pension funds). However, is there a potential possibility of making future additional pension serve as an incentive to invest in NPF?

Therefore, we put forward the following hypotheses (assumptions that will be verified experimentally for a possible solution of the problem). First, is there a connection between the amount of the initial deposit, the investment portfolio of the NPF and the future payouts to the participants? Secondly, does NPF need to take into account the main indicators of the impact on the payment and model the investment portfolio so that to provide payouts to the participants under minimal investment?

\section{LITERATURE REVIEW}

Scientists study the activities and functioning of non-state pension funds from different positions, in particular, from the standpoint of the specifics of the pension insurance market. Such researchers as Gregorio Impavido, Esperanza Lasagabaster, Manuel García Huitrón (2009) and Valdés-Prieto (2007) describe the retirement industry as "quasi-markets" taking into account the demand and supply of non-state pension fund.

This prompts NPF to compete with other financial institutions, because participation in non-state pension provision is optional according to Claessens S. (2009), providing the required level of motivation to reduce costs in the pension industry, even in the absence of perfect competition in it Benediktsson $\mathrm{H}$. (2001). Competition in the market of pension services, according to Severinson C. and Stewart F. (2012), allows minimizing the impact of operations with pension funds on the stock market situation and diversifying managerial risks.

Considerable attention is paid to the assessment of the financial state of non-state pension funds by the following researchers as: Bateman H., Thorp S. (2006); Kominek Z. (2012); Koulis A., Botsaris C. (2009).

The works of such scholars as: Clark G. Bennett (2001), Gordon L. Clark, Daniel Mansfield and Adam Tickell (2002), Sinicakova and Gavurova (2017), are devoted to research into the functioning of the NPF's financial services market from the standpoint of economic and mathematical modelling, which analyze the various approaches to management and models for making investment decisions that relate to retirement obligations.

Greg Mennis, Susan Banta and David Draine (May, 2018), Farrell J. and Shoag D. (2016, September) investigate the activities of non-state pension funds in an unstable economy, in particular the vulnerability of various pension systems to the economic downturn or a long period of low investment profitability. Some scholars offer to use stress testing for timely detect and prevent large losses from non-return of investments and decrease in revenues from contributions. 
On the other hand, Loretti I. Dobrescu, Hazel Bateman, B.R. Newell, Andreas Ortmann, S. Thorp (2017), are approaching this issue. They proposed to use a structured dynamic model based on simulated method of moments to assess both the prevalence of non-payment and its impact on pension savings.

Pitselisa G., GrigoriadouaV., Badounasa I. (2015) are engaged in various approaches to improving the system of non-state pension provision using the mathematical apparatus - with the help of a logarithmic model determine the stability of the pension fund; Bikker J. (2013) designs the optimal size of the pension fund.

Owadally M. I. and Haberman S. (2001) pay attention to the financial flows of the non-state pension fund for a group of participants based on their solvency. Josh McGee. Michelle H. Welch (March 2016) is involved in the simulation of payments to members of a non-state pension fund based on the methods of financial mathematics; propose to pay off the future value of money.

Such scholars as: Chen C. and Hung W. (2009); D. Vukovic and V. Prosin, 2018; C. Papachristodoulou and E. Dotzauer (2004); H. R. Golmakani and F. Mehrshad (2011); P. Śliwiński and M. Lobza (2017).; K. Pendaraki, C. Zopounidis and M. Doumpos (2005) and others paid attention to the problems of the formation of an optimal portfolio.

Investment activity of non-state pension funds is highlighted in the works of such researches as: PittWatson D., Sier C., Moorjani S., Mann H. (2014), Bogle J. (2014).

Summarizing the developments on this issue and the obtained results of the formation of an investment portfolio in non-state pension funds we can conclude about the incompleteness of research in this direction and update the need for a model search that would minimize investments into the investment portfolio and allow them to make pension payments in full.

\section{RESEARCH METHODS}

In Ukraine, the NPF offer a cumulative model of the pension system. Contributions of participants are used to finance pension savings and accumulated on an individual account. It was been defined the main directions, which require further research, despite that NPF occupied its niche in the financial services market after analyzing their activities through system analysis.

We used the MARSpline module, as main task of NPF is to make payments. This made it possible to calculate the regression model in a multidimensional space due to the main functions and to construct the spline surfaces of the dependence of payments on revenues to the pension fund, investment income and expenditures on account of pension assets. The obtained regression model established the relationships between variables with a rather precise approximation.

Taking into account the research of scientists on the given subjects and methods of economic and mathematical modelling, we have constructed a model that defines the necessary initial amount for the formation of an investment portfolio in a non-state pension fund, taking into account payments to participants.

\section{RESULTS}

Non-state pension provision is a component of the third level of the pension system (Andrushkiv, Vovk, \& Vovk, 2012; Hlibova, 2017). These institutions provide non-state pension provision services, the main purpose of which is to ensure that people receive additional mandatory state pension insurance benefits. Each member of the NPF is the owner of his pension savings, which is formed at the expense of pension contributions paid in his favour and part of the investment income received by the NPF from investing (Palme, 2007). 
The number of pension contracts concluded, the number of participants in the NPF of Ukraine is increasing (Fig. 1), but it represents a scanty share in the structure of the employed population of Ukraine - about 2\%, since Ukrainian citizens have low incomes and lack sufficient information about the benefits of such funds does not show them proper trust. For comparison, $72 \%$ of the able-bodied population of the United States participate in the NPF of $65 \%$ of the population of Sweden, $28 \%$ of the population of Poland (Meleschko, 2009).

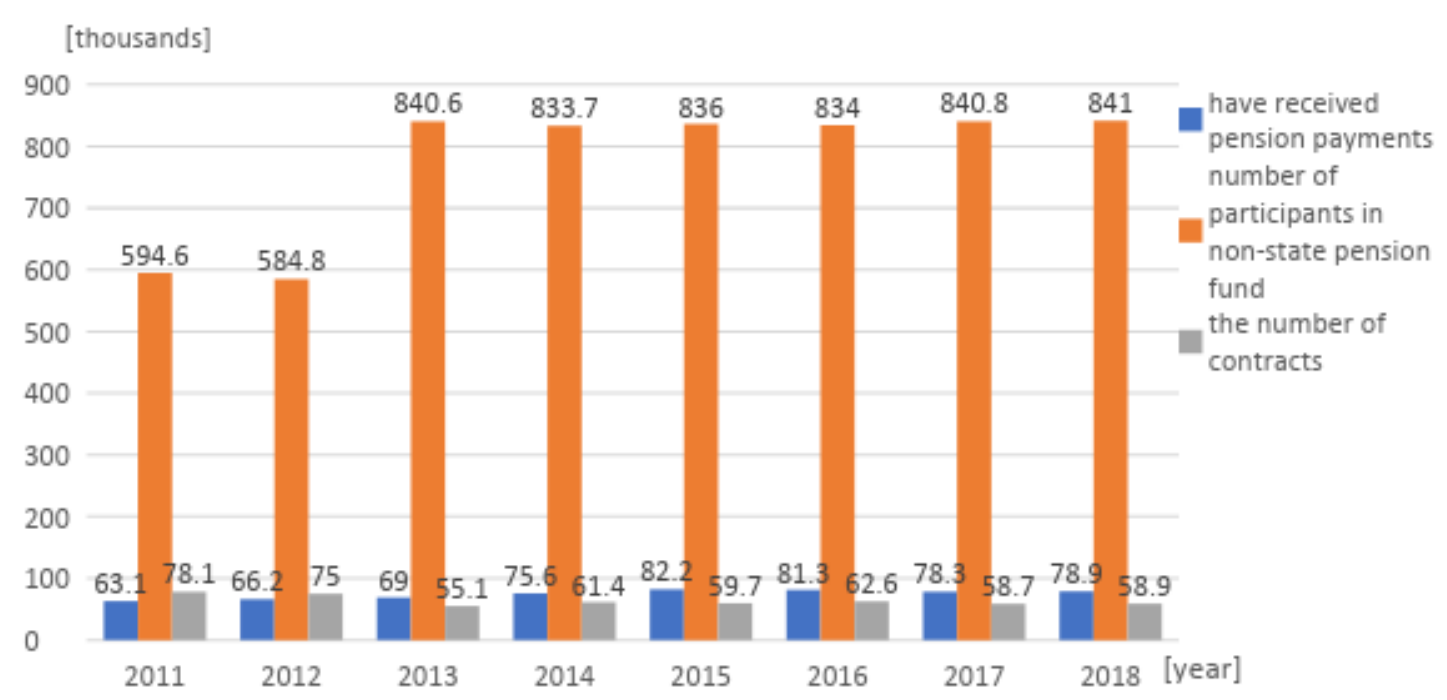

Figure1. Dynamics of the number of citizens in non-state pension funds Source: author's elaboration on the basis of (NFP, 2018)

Analysis of the activity of the non-state pension provision market (Tab. 1) shows that the amount of pension payments for the NPF participants increases together with the amount of pension contributions and the amount of financial resources in the form of the attracted pension contributions is insignificant in order to ensure the possibility of diversifying pension assets into profitable financial instruments.

Table 1

Dynamics of the main indicators of NPF activity in Ukraine

\begin{tabular}{|l|c|c|c|c|c|c|c|c|}
\hline \multicolumn{1}{|c|}{ Indicators } & $\mathbf{2 0 1 1}$ & $\mathbf{2 0 0 1 2}$ & $\mathbf{2 0 0 1 3}$ & $\mathbf{2 0 1 4}$ & $\mathbf{2 0 1 5}$ & $\mathbf{2 0 1 6}$ & $\mathbf{2 0 1 7}$ & $\mathbf{3 1 . 0 3 . 1 8}$ \\
\hline $\begin{array}{l}\text { Total value of assets, } \\
\text { million UAH }\end{array}$ & 1386.9 & 1660.1 & 2089.8 & 2469.2 & 1980.0 & 2138.7 & 2465.6 & 2485.2 \\
\hline $\begin{array}{l}\text { Pension contributions, } \\
\text { total, million UAH }\end{array}$ & 1102.0 & 1313.7 & 1587.5 & 1808.2 & 1886.8 & 1895.2 & 1897.3 & 1910.4 \\
\hline $\begin{array}{l}\text { Pension payments, } \\
\text { million UAH }\end{array}$ & 208.9 & 251.9 & 300.2 & 421.4 & 557.1 & 629.9 & 696.3 & 723.2 \\
\hline $\begin{array}{l}\text { Amount of investment } \\
\text { income, million UAH }\end{array}$ & 559.9 & 727.0 & 953.3 & 1266.0 & 872.2 & 1080.5 & 1455.5 & 1468.5 \\
\hline $\begin{array}{l}\text { Profit from investing } \\
\text { non-state pension fund } \\
\text { assets, million UAH }\end{array}$ & 673.3 & 620.3 & 818.0 & 1095.0 & 657.0 & 834.8 & 1183.9 & 1185.1 \\
\hline $\begin{array}{l}\text { Amount of expenses } \\
\text { that are reimbursed by } \\
\text { pension assets, million } \\
\text { UAH }\end{array}$ & 86.6 & 106.6 & 135.3 & 171.0 & 215.2 & 245.7 & 271.5 & 283.4 \\
\hline
\end{tabular}

Source: author's elaboration on the basis of NFP (2018) (https://www.nfp.gov.ua/ua/Informatsiia-pro-stan-irozvytok-nederzhavnoho-pensiinoho-zabezpechennia-Ukrainy.html) 
Payments for members of pension funds depend on pension contributions and although contributions significantly outweigh the payments and costs may come a moment that this will not be enough, moreover that contributions for NPF participants are carried out in complex percentages, and an unstable economic situation can lead to volatility of contributions. It leads to the fact that non-state pension funds have to invest into investment projects in order to obtain an additional source of income to ensure future payments.

Let's consider how pension benefits depend on pension contributions from investing assets and expenses, which are reimbursed at the expense of pension assets (Table 1).

Dependence is described by using the general equation of the MARSpline model:

$$
y=f(X)=\beta_{0}+\sum_{m=1}^{M} \beta_{m} h_{m}(X)
$$

where $h_{m}(X)$ - the basic functions; $m$ - the number of basic functions; $\beta_{0}$ i $\beta_{m}$ - the coefficients of the model.

This model will enable to calculate the regression model in a multidimensional space and to construct spline surfaces through the main functions (Friedman, 1991).

The advantage of this module is that it uses piecewise and linear basis functions when constructing a model that is it distributes the space of output variables of a large range. The obtained regression model establishes relationships between variables, when they have no monotonous nature, with a rather precise approximation, and there are no any assumptions about the nature of the functional connection (Zeluch, 2012).

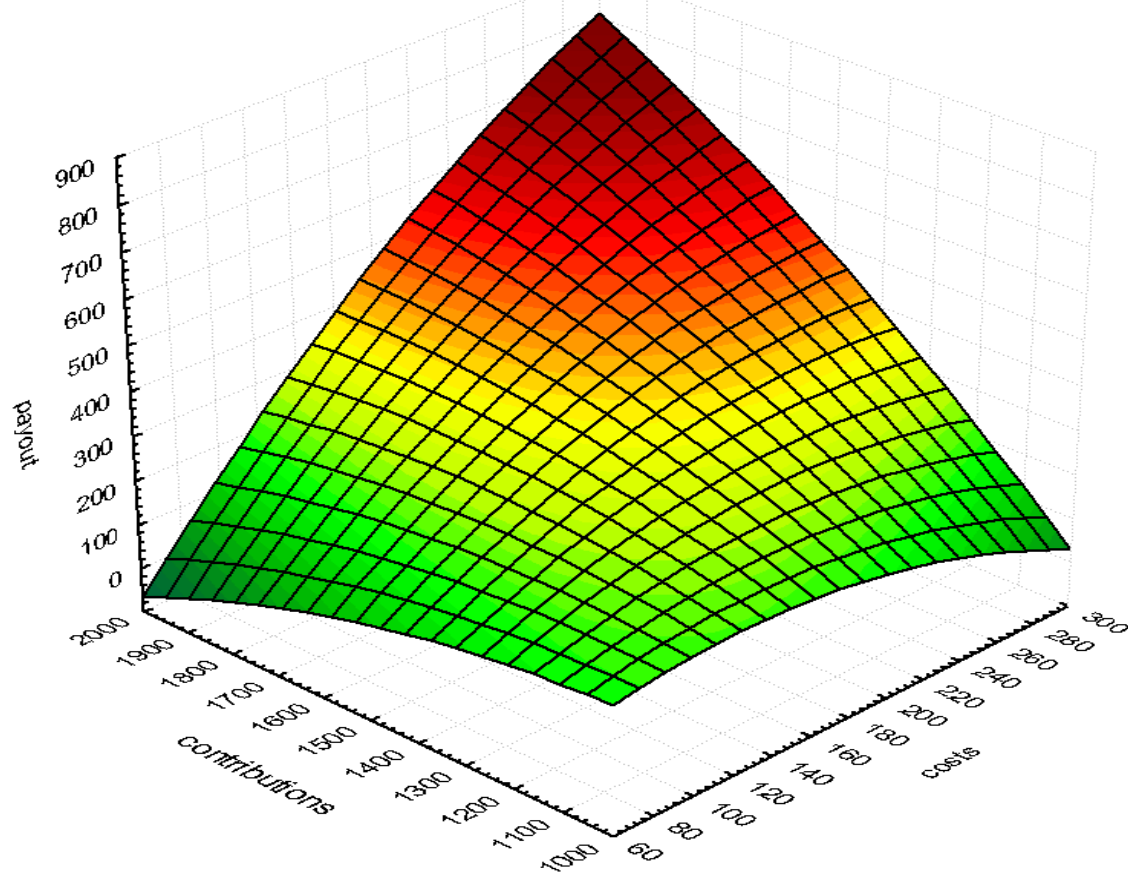

Figure 2. The quadratic spline surface of dependencies of NPF payments

(from the costs associated with the implementation of non-state pension provision and from the amount of revenues to the NPF)

Source: Created by the authors (by means of STATISTICS 8.0 according to the Table 1) 
Using the MARSpline Statistics program we have received spline quadratic surfaces (Fig. 2 and 3). The surface (Fig. 2) shows the dependence of payments on contributions and expenses, which are characterized by the equation:

$$
W=197-2.7 x+0.1 y+0.006 x^{2}+0.004 x y-0.0002 y^{2}
$$

where: $x$ - costs, $y$ - contributions.

The amount of payments increases with an increase in the amount of contributions and a decrease in costs on the one hand and on the other (Figure 3) - a reduction in costs with a stable income also increases the amount of payments and is described by the equation:

$$
W=117+3.03 x-0.39 z+0.007 x^{2}-0.003 x z+0.0004 z^{2}
$$

where: $x$ - costs, $z$ - income.

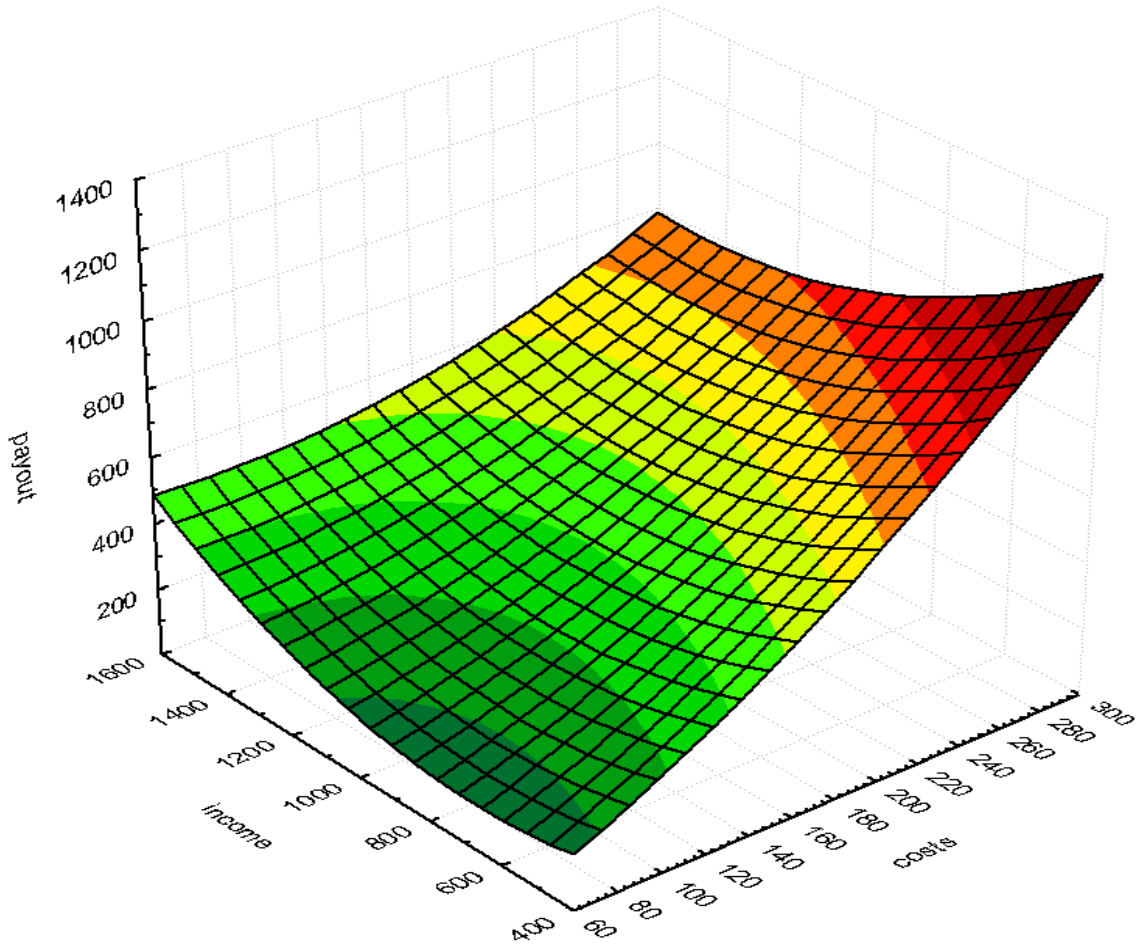

Figure 3. Quadratic spline surface of dependence of NPF payments on costs that is related to the implementation of non-state pension provision and from profit (loss) from investing assets Source: Created by the authors (by means of STATISTICA 8.0 according to the Table 1)

Since the payments depend simultaneously on costs and contributions, as well as income from investment activities, they must be combined with the help of a multi-factor model, and as a result we obtain the following result:

$$
W=-6.3+2.9 x-0.02 y-0.04 z
$$


For this model: $R^{2}=0.99 ; F_{\text {роз }}=576>F_{\text {табл }}=6.39 ;\left(k_{1}=k_{2}=4 ; \alpha=0.05\right)$, which indicates the adequacy of the model.

You cannot always use the multi-factor model described by formula (4) for the payment of benefits to members of the non-state pension fund. It is necessary to consider investment activity as an additional source of income for a non-state pension fund.

The dynamics of NPF's investment income due to its origin should be analyzed with some caution, because it is not formed as a result of investing in the development of the national economy.

The purpose of investment of pension assets is, first of all, preservation of pension savings of citizens; therefore, NPFs are the predominant areas for investing in pension assets are deposits in banks, corporate bonds, whose issuers are residents of Ukraine, shares of Ukrainian issuers, securities whose income are guaranteed by the Cabinet of Ministers of Ukraine, securities of foreign issuers, mortgage bonds, real estate, bank metals, shares acquired as a result of the transformation of a legal entity whose corporate rights were in the assets of a pension fund in a joint-stock company (Zminenko, 2010).

The investment policy of non-state pension funds is limited by legislative normative requirements to the formation of an investment portfolio of pension assets, namely the restrictions on the level of maximum share of one or another asset in the portfolio (Tab. 2) (VSE, 2012).

Table 2

Restriction of the share of investment of pension assets of non-state pension funds in Ukraine

\begin{tabular}{|c|c|c|}
\hline Financial instrument & $\begin{array}{c}\text { Maximum share in total asset } \\
\text { value, } \%\end{array}$ & $\begin{array}{c}\text { Interest rates on financial } \\
\text { instruments, } \%\end{array}$ \\
\hline bank deposits & no more than 50 & $11-18$ \\
\hline securities of one issuer & no more than 5 & 23.1 \\
\hline $\begin{array}{l}\text { securities that incomes are } \\
\text { guaranteed by the Cabinet of } \\
\text { Ministers of Ukraine }\end{array}$ & no more than 50 & $16.7-18$ \\
\hline $\begin{array}{l}\text { bonds of enterprises, issuers of } \\
\text { which are residents of Ukraine }\end{array}$ & no more than 40 & $16-19$ \\
\hline securities of foreign issuers & no more than 20 & $16-19$ \\
\hline mortgage bonds & no more than 40 & $10-15$ \\
\hline real estate objects & no more than 10 & $10-15$ \\
\hline banking metals & no more than 10 & $20-23$ \\
\hline $\begin{array}{l}\text { other assets that are not prohibited } \\
\text { by the legislation of Ukraine (shares } \\
\text { acquired as a result of the } \\
\text { conversion of a legal entity, whose } \\
\text { corporate rights were in the assets } \\
\text { of a pension fund in a joint-stock } \\
\text { company) }\end{array}$ & no more than 5 & $>=10$ \\
\hline
\end{tabular}

Source: VSE, 2018. Retrieved from http://www.vsenpf.com.ua/reporting.html

The investment portfolio represents a system of assets, each asset having its own statistical characteristics. We will use a utility coefficient to construct the model that can be both positive and negative when the stock price falls.

The main task of NPF is to provide future payments to participants. He needs to make payments in the amount of 10 million UAH according to concluded contracts during $T$ months / years. Denote this through $t-\mathrm{t}$ - index of the corresponding planning period (month, year), $t=\underline{1 . T}$ t. Allocation for payments in period $t$ are in accordance with contracts $q_{t}$ million $\mathrm{UAH}$. 
It is necessary to form an investment portfolio for the complete calculation and observance of contractual conditions of the NPF. Since NPF current payments are less than total payments and total expenses, the remaining balances can be invested in accordance with the Table 2 . The investment activities will give additional profit before the next payments; however, not all necessary amount of $\mathcal{Q}$ should be invested, but much smaller. The amount will depend on the available financial resources and the optimal organization of the investment process. Often NPF expects to focus its investment activity on $n$ investment projects.

Let's denote $i$ as the index of the project $(i=\underline{1} . n)$. We know the quantitative characteristics of the respective investment projects: $p_{i}-$ interest rate of the $i^{\text {th }}$ project; $v_{i}-$ the value of the $i^{\text {th }}$ asset. The main objective of the non-state pension fund - with the given investment opportunities and the approved schedule of payments to participants of the non-state pension fund, is to calculate a forecast strategy that will minimize the required initial amount of cash, which NPF will refer to payments in accordance with the terms of the contracts.

We introduce the following additional notation to construct a formalized model of this problem:

$\left(\alpha_{i t}\right)$ - is a vector that reflects the process of investing in the $i$-th investment project in period $t$, or its absence

$$
\alpha_{i t}=\left\{\begin{array}{l}
1, \text { if the investment in the } i-t h \text { project in the period } t \\
0, \text { if the attachment is not in } i-\text { th project in period } t
\end{array}\right.
$$

$\left(\alpha_{i t}^{*}\right)$ is a vector that shows the value of the utility of the $i \tau^{\text {th }}$ project in the period $t$;

$$
\alpha_{i t}^{*}=\left\{\begin{array}{l}
p_{i}, \text { if the reversion from the } i-\text { th project occurs in the period } t \\
0, \text { if the return from the } i-\text { th project is absent in the period } t
\end{array}\right.
$$

Unknown variables of this task will be:

$z$-initial amount of available financial resources;

$x_{i t}-$ the amount of financial resources that are aimed to the $i_{-}$-th investment project at the beginning of the period $t$.

The mathematical model of the investment optimization task of NPF will take the form given the introduction of the notation - to calculate the minimum initial amount of necessary financial resources, which will ensure the implementation of contractual obligations that are:

$$
r \rightarrow \min
$$

in the implementation of the following conditions:

1) balance sheet limitation on the structure of the investment portfolio for the initial periods:

$$
\sum_{i=1}^{n} \alpha_{i t} \cdot x_{i t}=z, t=1
$$

2) balance sheet limitation on the structure of the investment portfolio for the following periods:

$$
\sum_{i=1}^{n} \alpha_{i t}^{*} \cdot x_{i t}=q_{t}, t=\underline{2, T},
$$


3) limits on the value of assets:

$$
x_{i t} \leq v_{i} Z
$$

4) on the integrity of variables:

$$
z \geq 0 . x_{i t} \geq 0 . i=\underline{1 . n} . t=\underline{1 . T} .
$$

We use the data of the non-state pension fund "VSE", for realization of this model, while interest rates on deposits in investment projects will be taken conditionally according to the general interest rates (Tab. 2). The main task of the NPF is the implementation of payments (VSE, 2018), since there is no data on interest rates on investment, following the basic requirements, in particular, we will not violate the main objective of the study and demonstrate the application this model.

Table 3

Incoming data for implementation of the model for NPF "VSE"

\begin{tabular}{|l|c|c|c|c|c|}
\hline \multirow{2}{*}{ Investment object } & \multicolumn{5}{c|}{ Interest rate } \\
\cline { 2 - 6 } & $\mathbf{2 0 1 4}$ & $\mathbf{2 0 1 5}$ & $\mathbf{2 0 1 6}$ & $\mathbf{2 0 1 7}$ & $\mathbf{1 . 0 9 . 2 0 1 8}$ \\
\hline Supplementary (deposit) of bank accounts & 0.12 & 0.15 & 0.14 & 0.14 & 0.15 \\
\hline $\begin{array}{l}\text { Securities the income that are guaranteed by } \\
\text { the Cabinet of Ministers }\end{array}$ & 0.16 & -0.18 & 0.11 & 0.17 & -0.1 \\
\hline $\begin{array}{l}\text { Bonds of enterprises, issuers of which are } \\
\text { residents of Ukraine }\end{array}$ & & 0.19 & 0.17 & & \\
\hline Shares of Ukrainian issuers & 0.231 & 0.231 & 0.231 & 0.231 & 0.231 \\
\hline Real estate objects & 0.1 & 0.14 & 0.11 & 0.12 & 0.13 \\
\hline Bank metals & 0.2 & 0.23 & & 0.21 & 0.2 \\
\hline Movement of fixed assets involved in the model (million UAH) & \multicolumn{3}{|c|}{} \\
\hline Pension payments & 2132270 & 2509170 & 1539690 & 2372610 & 2240001 \\
\hline
\end{tabular}

Source: it is the author's elaboration on the basis of (VSE, 2018). Retrieved from http://www.vsenpf.com.ua/reporting.html

Using the above sources of information, we established that NPF with participants of the non-state pension fund concluded contractual obligations in the amount of $10793391 \mathrm{UAH}$. In accordance with the concluded contracts for the second year it is necessary to pay $2132270 \mathrm{UAH}$ for the third - 2509170 UAH, for the fourth - $1539690 \mathrm{UAH}$, for the fifth - $2372261 \mathrm{UAH}$, and the sixth - $2240000 \mathrm{UAH}$.

The NPF forms an investment portfolio to fully calculate that will give you an opportunity to generate additional income until the full payment. As investment activity gives you an opportunity to get additional profit before the date of full payments, the investment should not be invested in the entire amount of 10 793391 UAH, but much less, the NPF decided to direct its investment activity in six areas (Tab. 3). We can calculate the NPF's prognostic strategy for investment data and an approved pension benefit schedule that minimizes the initial amount of available cash.

The model of the numerical expression for NPF "VSE", will look like as follow:

under the following conditions:

$$
z \rightarrow \min
$$

1) balance sheet terms for distribution of investment portfolio funds at the beginning of the period (each year): 


$\begin{array}{ll}t=1: & z=x_{1}+x_{2}+x_{3}+x_{4}+x_{5}+x_{6} \rightarrow \min \\ t=2: & 0.12 x_{1}+0.16 x_{2}+0.231 x_{4}+0.1 x_{5}+0.2 x_{6}=2132270 \\ \mathrm{t}=3 & 0.15 x_{1}-0.18 x_{2}+0.19 x_{3}+0.231 x_{4}+0.14 x_{5}+0.23 x_{6}=2509170 \\ t=4: & 0.14 x_{1}+0.11 x_{2}+0.17 x_{3}+0.231 x_{4}+0.11 x_{5}=1539690 \\ t=5: & 0.14 x_{1}+0.17 x_{2}+0.231 x_{4}+0.12 x_{5}+0.21 x_{6}=2372610 \\ t=6: & 0.15 x_{1}-0.1 x_{2}+0.18 x_{3}+0.231 x_{4}+0.13 x_{5}+0.2 x_{6}=224001\end{array}$

1) limits on the value of assets:

2) on the nonnegative of variables:

$$
\begin{gathered}
x_{1} \leq 0.5 z \\
x_{2} \leq 0.4 z \\
x_{3} \leq 0.05 z \\
x_{4} \leq 0.1 z \\
x_{5} \leq 0.5 z \\
x_{6} \leq 0.1 z
\end{gathered}
$$

$$
z \geq 0 . x_{i t} \geq 0 . i=\underline{1.6} . t=\underline{1.6} .
$$

The following results are obtained as a result of the model implementation: it is necessary to invest $2717098 \mathrm{UAH}$, to deposit accounts; bonds of enterprises, issuers of which are residents of Ukraine -161733 UAH; shares of Ukrainian issuers -3990619 UAH, real estate objects - $873935 \mathrm{UAH}$, precious metals $664159 \mathrm{UAH}$. It is necessary to add $8407545.62 \mathrm{UAH}$, that in total, the balance in securities that incomes, is guaranteed by the Cabinet of Ministers of Ukraine.

Such distribution of funds will enable to pay $2132270 \mathrm{UAH}$ for the second year, the third one $2509170 \mathrm{UAH}$, the fourth $-1539690 \mathrm{UAH}$, the fifth $-2372261 \mathrm{UAH}$, and the sixth - $2240000 \mathrm{UAH}$ that is to fulfil all contractual obligations.

\section{DISCUSSION OF THE RESULTS}

The conducted study made it possible to reveal the main factors that influence payouts to participants of the non-state pension fund. The application of the MARSPline model and the resultant regression equations enable us to determine the general dependencies of payments on revenues, income from investment activities and costs.

The generalized economic and mathematical model of an investment portfolio in the NPF minimizes initial investment and ensuring future payments to participants. The model can be adapted to any non-state fund, as shown by the example of the NPF "VSE".

In addition, it should be noted that, in our opinion, the conducted study allowed to form new scientific problems that have important theoretical and practical significance and could become the subject of further scientific researches. These, primarily include:

- optimization of management of financial capital of business entities of different forms of ownership;

- activation of capital investment by implicating instruments of the financial capital market.

A possible direction for further research on this issue is also a consideration in this model. The future value of money and inflation are accounted for through additional substantiation and changes in individual components of the calculations. 


\section{CONCLUSIONS}

Accumulation in NPFs should be as much as possible protected from inflation, risk investments, and bankruptcies. As a result, the transparency of their activity data is a requirement of time. Herewith, the issue of not only raising funds, but also their effective and well thought-out use becomes of paramount importance.

With available financial resources, NPF has the ability to apply this model in all subtypes of investment restrictions and add the magnitude of the risk of each investment project in order to obtain a more detailed result. It can also be used to predict the activities of other financial intermediaries who have similar operations of accumulation of funds in investment projects, as well as in insurance organizations that provide life insurance services in the future, not only in Ukraine but also in other countries.

In addition, the developed organizational, methodological and methodical tools can be used to solve a wide range of more narrow and specific relevant scientific and theoretical applied tasks related to the construction of models of business entities.

\section{REFERENCES}

Andrushkiv, B. M., Vovk, Y., \& Vovk, I. P. (2012). Resursonomika: teoretychni ta prykladni aspekty [Resourcenomy: theoretical and applied aspects]. Ternohraf, Ternopil.

Bateman, H., \& Thorp, S. (2007). Decentralized investment management: an analysis of non-profit pension funds. Journal of Pension Economics \& Finance, 6(1), 21-44.

Benediktsson, H. C., Herbertsson, T. T., \& Michael Orszag, J. (2001). The charge ratio on individual accounts and investment plans in Iceland. Applied Economics, 33(8), 979-987.

Bilan, Y., Gazda, J., \& Godziszewski B. (2012). Derivative variables as indicators of output gap in Poland and Ukraine. Actual Problems of Economics, 3(129), 331-340.

Bikker, J. A. (2017). Is there an optimal pension fund size?: A scale-economy analysis of administrative and investment costs. In Pension Fund Economics and Finance (pp. 25-56). Routledge.

Bogle, J. C. (2014). The arithmetic of "all-in" investment expenses. Financial Analysts Journal, 70(1), 13-21. doi:https://www.doi.org/10.2469/ faj.v70.n1.1.

Chen, C. T., \& Hung, W. Z. (2009). Applying ELECTRE and maximizing deviation method for stock portfolio selection under fuzzy environment. In Opportunities and Challenges for Next-Generation Applied Intelligence (pp. 8591). Springer, Berlin, Heidelberg.

Claessens, S. (2009). Competition in the financial sector: overview of competition policies. The World Bank Research Observer, 24(1), 83-118.

Clark, G. L., \& Bennett, P. (2001). Dutch sector-wide supplementary pensions: fund governance, European competition policy, and the geography of finance. Environment and Planning A, 33(1), 27-48.

Clark, G. L., Mansfield, D., \& Tickell, A. (2002). Global finance and the German model: German corporations, market incentives, and the management of employer-sponsored pension institutions. Transactions of the Institute of British Geographers, 27(1), 91-110.

Dobrescu, L. I., Fan, X., Bateman, H., Newell, B. R., Ortmann, A., \& Thorp, S. (2017). Retirement savings: A tale of decisions and defaults. The Economic Journal, 128(610), 1047-1094.

Farrell, J., \& Shoag, D. (2016). Risky Choices: Simulating Public Pension Funding Stress with Realistic Shocks. Harvard Kennedy School of Government Faculty Research Working Paper Series.

Friedman, J. H. (1991). Multivariate adaptive regression splines. The Annals of Statistics, 19, 1-67.

FrostRB. (2012). Conflicts of interest between asset managers and their customers: Identifying and mitigating the risks. London. Financial Services Authority. Retrieved November 19, 2018, from http://www.frostrb.com/perch/resources/conflicts-of-interestnov2012-2.pdf

Gazda, J., \& Puziak, M. (2012). The Sources of Economic Growth in the Regions. In Stages of the Convergence in the Developed European Economies; Kokocinska, M., Ed.; Poznan University of Economics Press: Poznan, Poland, 107-125. 
Głuszak, M. (2018). Externalities and House Prices: A Stated Preferences Approach. Entrepreneurial Business and Economics Review, 6(4), 181-196.

Golmakani, H. R., \& Fazel, M. (2011). Constrained portfolio selection using particle swarm optimization. Expert Systems with Applications, 38(7), 8327-8335.

Haberman, S., \& Owadally, I. (2001, June). Modelling defined benefit pension schemes: funding and asset valuation. In International Actuarial Association International Pensions Seminar, Brighton.

Impavido, G., Lasagabaster, E., \& García-Huitrón, M. (2010). Competition and Asset Allocation Challenges for Mandatory DC Pensions: New Policy Directions. Brookings Institution and World Bank.

Khlybova, T., \& Chernenok, K. (2017). Rozvytok nederzhavnykh pensiinykh fondiv v Ukraini [Development of NonState Pension Funds in Ukraine]. Young Scientist, 47(7), 486-489.

Kominek, Z. (2012). Regulatory induced herding? Evidence from Polish pension funds. Economic Change and Restructuring, 45(1-2), 97-119.

Koulis, A., \& Botsaris, C. (2009, September). The behavior of pension fund in the primary market: a theoretical approach. In Proceedings of the 9th WSEAS international conference on Simulation, modelling and optimization (pp. 212216). World Scientific and Engineering Academy and Society (WSEAS).

Luchko, M. (2017). Economy of Ukraine: The analysis of the innovative way of the development. Economics, Management and Sustainability, 2(2), 95-103. doi:10.14254/jems.2017.2-2.10

Mačí, J., \& Valentová Hovorková, V. (2017). Loan versus Bond Financing of Czech Companies and the influence of the Global Recession. Journal of Competitiveness, 9(1), 72-88.

McGee, J., \& Welch, M. H. (2016). Modeling Pension Benefits. Urban.org, March. Washington, DC: Urban Institute.

Meleshko, O.V. (2009). Osoblyvosti rozvytku nederzhavnykh pensiinykh fondiv: Zarubizhnyi dosvid [Features of the development of non-state pension funds: foreign experience]. Stratebiia Rozyytku Ukrainy: Sotsiolobiia, Ekonomika, Pravo = Development Strategy of Ukraine: Sociology, Economics, Law, 1-2, 250-254.

Mennis, G., Banta, S., \& Draine, D. (2018). Assessing the Risk of Fiscal Distress for Public Pensions: State Stress Test Analysis. M-RCBG Associate Working Paper Series, 92.

NFP. (2018). Results of the development of the system of non-state pension provision. Retrieved from https://www.nfp.gov.ua/ua/Informatsiia-pro-stan-i-rozvytok-nederzhavnoho-pensiinoho-zabezpechenniaUkrainy.html

Palme, M., Sundén, A., \& Söderlind, P. (2007). How do individual accounts work in the Swedish pension system?. Journal of the European Economic Association, 5(2-3), 636-646.

Papahristodoulou, C., \& Dotzauer, E. (2004). Optimal portfolios using linear programming models. Journal of the Operational Research Society, 55(11), 1169-1177.

Pendaraki, K., Zopounidis, C., \& Doumpos, M. (2005). On the construction of mutual fund portfolios: A multicriteria methodology and an application to the Greek market of equity mutual funds. European Journal of Operational Research, 163(2), 462-481.

Pitselis, G., Grigoriadou, V., \& Badounas, I. (2015). Robust loss reserving in a log-linear model. Insurance: Mathematics and Economics, 64, 14-27.

Pitt-Watson, D., Sier, C., Moorjani, S., \& Mann, H. (2014). Investment costs: An unknown quantity. A literature review and state of play analysis. Retrieved from http://hb.betterregulation.com/external/Investment $\% 20 \operatorname{costs} \%$ $20 \mathrm{An} \% 20$ unknown $\% 20$ quantity.

Rozhelyuk, V., Khorunzhak, N., \& Luchko, M. (2018). Institutional approach to arrangement of business accounting and its conceptual foundations. Financial and Credit Activity: Problems of Theory and Practice, 4(27), 231-241. doi:10.18371/ fcaptp.v4i27.154199

Severinson, C., \& Stewart, F. (2012). Review of the Swedish National Pension Funds. OECD Working Papers on Finance, Insurance and Private Pensions, no. 17, OECD Publishing.

Sinicakova, M., \& Gavurova, B. (2017). Single monetary policy versus macroeconomic fundamentals in Slovakia. Ekonomicky casopis, 65(2), 158-172.

Śliwiński, P., \& Lobza, M. (2017). The impact of global risk on the performance of socially responsible and conventional stock indices. Equilibrium. Quarterly Journal of Economics and Economic Policy, 12(4), 657-674.

Tselykh, V. R. (2012). Mnogomernye adaptivnye regressionnye splainy [Multidimensional adaptive regression splines]. Mashinnoe Obuchenie i Analiz. Dannykh = Machine Learning and Data Analysis, 3, 272-278. 
Valdés-Prieto, S. (2007). Pension reform and the development of pension systems: An evaluation of Word Bank assistance. Backeground paper, Regional Summary: Latin America and the Caribbean, Independent Evaluation Group. Washington: World Bank.

Vukovic, D., \& Prosin, V. (2018). The prospective low risk hedge fund capital allocation line model: evidence from the debt market. Oeconomia Copernicana, 9(3), 419-439.

VSE. (2012). Investytsiina deklaratsiia NPF VSI [Investment declaration GC VSE]. Retrieved from http://vseswit.com.ua/data/upload/file/Dok\%20NPF\%20Vse/121002-Invest_deklaraciya_NPF_ VSI_nova_redakciya.pdf

VSE. (2018). Rezultaty diialnosti NPF VSI [Results of activity GC VSE]. Retrieved from http://www.vsenpf.com.ua/reporting.html

Vychytilova, J. (2018). Stock Market Development Beyond the GFC: The Case of V4 Countries. Journal of Competitiveness, 10(1), 149-163.

Zmiienko, M. O. (2012). Sutnist nederzhavnykh pensiinykh fondiv yak instytutsiinykh investoriv [The essence of nonstate pension funds as institutional investors]. Problemy Pidvyshchennia Efektyonosti Infrastruktury = Problems of Increasing the Efficiency of Infrastructure, 30(30). 